\title{
EFFECT OF PROTEIN ON PERFORMANCE AND HAEMATOLOGY OF BROILERS FED CASSAVA PEEL-BASED DIETS
}

\author{
EFECTO DE LA PROTEÍNA SOBRE EL RENDIMIENTO Y HEMATOLOGÍA DE BROILERS \\ ALIMENTADOS A BASE DE RESIDUO DE MANDIOCA
}

\author{
Egbunike, G.N. ${ }^{1}$, E.A. Agiang ${ }^{2}$, A.O. Owosibo ${ }^{3}$ and A.A. Fatufe ${ }^{4}$
}

\begin{abstract}
${ }^{1}$ Animal Physiology Laboratory. Department of Animal Science. University of Ibadan. Ibadan. Nigeria. ${ }^{2}$ Department of Animal Science. University of Calabar. Calabar. Nigeria. ${ }^{3}$ Federal College of Animal Health and Production Technology. I.A.R.\& T. Moor Plantation. Ibadan. Nigeria. ${ }^{4}$ Obafemi Awolowo University. Ile-lfe. Osun State. Nigeria. aafatufe@oauife.edu.ng
\end{abstract}

\section{AdDitiOnAL KEYWORDS}

Unconventional feedstuff. Blood parameters.

\section{SUMMARY}

A experiment was conducted to investigate the influence of the protein source on the performance and haematology of broiler chickens on cassava peel-based diets using fishmeal and groundnut cake as protein sources. In a 42 days feeding trial, a total of 192 Anak, four weeks old, unsexed broiler chickens with average initial body weight of $0.685 \pm 0.0027$ (mean $\pm S D$ ) were divided into two groups of diets containing $0,5,10$ and $15 \%$ dried cassava peel meal. Birds in one group had fishmeal as protein source while the other had groundnut cake. Each diet was offered to three pens of 8 birds each.

Final live weight, weekly weight gain, feed and protein intake, feed conversion and protein efficiency ratios, haematology and corpuscular indices were not significantly affected by protein source. Fishmeal inclusion resulted in higher $(p<0.001)$ serum albumin and lower $(p>0.05)$ serum cholesterol than groundnut cake inclusion. It was concluded that groundnut cake could serve as protein source for broiler chickens without any adverse effect on performance indices.

\section{RESUMEN}

En este estudio se investigó la influencia de la fuente de proteína sobre el rendimiento y hematología de broilers alimentados con dietas con harina de residuos de mandioca y harina de pescado o torta de cacahuete, como fuente de

Recibido: 24-9-07. Aceptado: 1-4-08.

\section{Palabras clave adicionales}

Alimentos alternativos. Parámetros sanguíneos.

proteína. Un total de 192 broilers Anak de un día de edad, no sexados, se distribuyeron (a la semana 5 ) en dos grupos de dietas que contenían 0, 5, 10 y $15 \%$ de harina de residuos de mandioca. A las aves de uno de los grupos se les suministró harina de pescado como fuente de proteína y a las del otro, torta de cacahuete. Cada dieta fue ofrecida a tres lotes de 8 aves cada uno.

El peso vivo final, la ganancia de peso semanal, los índices de conversión de pienso y de proteína, la hematología e índices corpusculares no fueron afectados por la fuente de proteína. La inclusión de harina de pescado dio lugar a mayores valores de albúmina sérica y menor cantidad de colesterol sérico que la inclusión de cacahuete. Se concluyó que la torta de cacahuete podría ser útil como fuente de proteína para broilers, sin efectos adversos sobre el rendimiento.

\section{INTRODUCTION}

That food scarcity is a plague in many developing countries of the world, including Nigeria where daily intake of animal protein per caput falls far below the normal intake as recommended by ILCA (1980) and FAO (1986), is not in doubt. To alleviate this situation, it has been realized that broiler production is the fastest and easiest route (Nworgu et al., 2000; Dipeolu et al., 1996; 
Larry, 1993) since they are prolific, possess a high feed conversion ratio and are accepted by all, irrespective of religion.

However, feed cost are presently very high and makes up to $60-70 \%$ (Larry, 1993) or $70-80 \%$ (Oruwari et al., 1995) of the total cost of production in Nigeria compared to $50-70 \%$ in developed countries (Thackie and Flenscher, 1995). This therefore highlights the importance of feed management to broiler producers. Thus it is necessary to reduce the cost of feeds in order to produce cheaper products without affecting profits. Since energy source constitutes $45-60 \%$ of finished feeds for monogastric animals (Tewe and Egbunike, 1992) and birds eat to satisfy their energy requirements (Sibbald, 1982), cassava products, roots, peels and leaves, have been exploited in the replacement of cereals like maize. Although inclusion of cassava peel in the diet increased feed intake and decreased body weight in broilers (Tewe, 1983), cassava peel can be used to cut down the cost of production and lead to an active and sustainable development in livestock production (Olorede et al., 2002). Some workers (Osei and Duodu, 1988; Agunbiade et al., 2002; Salami et al.,2003) recommended the inclusion of fermented cassava peel up to $15 \%$ in broiler diets with no adverse effects. Even the use of oven-dried cassava peels led to a reduction in weight gain but no effects on mortality and carcass quality.

However, for a reasonable performance of animals fed cassava-based diets, the rations must be nutritionally balanced and contain sufficient sulphur-containing amino acids (Tewe, 1992). Fishmeal has been widely used in poultry rations to provide the necessary amino acids although some variations still exist (Bello, 1984) especially due to processing method, type of fish and storage. Considering this variation and the fact that the cost of fishmeal has placed it out of reach to farmers in most developing countries, it becomes evident that some plant protein sources can be used in spite of their deficiency in sulphur-containing amino acids (Antunes and Sgarbieri, 1980; Barbour et al., 1993). These deficiencies are normally rectified by the addition of other protein sources or synthetic amino acids. The crude protein $(\%)$ and metabolisable energy (kcal/ $\mathrm{kg}$ ) contents of fish meal are 65 and 2580 , whereas groundnut cake meal has values of 40 and 2500 respectively (NRC, 1994).

In the light of the above, therefore, this study became necessary with the aim of studying the influence of the protein source on the performance and haematology of broiler chickens on cassava peel-based diets using fishmeal and groundnut cake.

\section{MATERIALSAND METHODS}

192 Anak unsexed four week-old broiler chickens were used for the experiment. They were fed on a commercial broiler starter diet (Livestock Feeds Plc.) until the end of the $4^{\text {th }}$ week and supplied drinking water ad libitum. They were also given all the necessary vaccinations and medication as and when due. Thereafter, the birds were randomly assigned to eight dietary treatments. Each diet was offered to three pens of 8 birds each. Diets 1 to 4 contained fishmeal (FM) as the protein source while groundnut cake (GNC) provided this nutrient in diets 5-8. In a 2 x 4 factorial design, each group of diets contained $0,5,10$ or $15 \%$ of cassava peel meal (table I). Thus the treatments were designated OFM, 5FM, 10FM and 15FM for the diets with fishmeal and $0 \mathrm{GNC}, 5 \mathrm{GNC}$, $10 \mathrm{GNC}$ and $15 \mathrm{GNC}$ for the diets with groundnut cake. In weeks 6 and 7 all the birds were supplied drinking water containing 3-nitro-4-hydroxylphenyl arsenic acid (prophylactic dose to control coccidiosis), at the rate of $8 \mathrm{mg} /$ litres of water, after which use was discontinued.

As the birds were assigned to the treatments (at the onset of week 5), they were weighed. The initial body weight of birds was $0.695 \pm 0.0027$ (mean \pm SD). Thereafter, feed intake and liveweight changes 
Table I. Ingredients and chemical composition of the experimental diets. (Ingredientes y composición nutritiva de las dietas experimentales).

\begin{tabular}{|c|c|c|c|c|c|c|c|c|}
\hline & \multicolumn{4}{|c|}{ Fish meal } & \multicolumn{4}{|c|}{ Groundnut cake } \\
\hline & OFM & $5 F M$ & 10FM & 15FM & OGNC & $5 \mathrm{GNC}$ & $10 \mathrm{GNC}$ & $15 \mathrm{GNC}$ \\
\hline $\begin{array}{l}\text { Ingredients (\%) } \\
\text { Maize }\end{array}$ & 49 & 44 & 39 & 34 & 49 & 44 & 39 & 34 \\
\hline Cassava peels & 0 & 5 & 10 & 15 & 0 & 5 & 10 & 15 \\
\hline Fish meal & 3 & 3 & 3 & 3 & 0 & 0 & 0 & 0 \\
\hline Groundnut cake & 0 & 0 & 0 & 0 & 14 & 14 & 14 & 14 \\
\hline Soya bean meal & 15 & 15 & 15 & 15 & 6 & 6 & 6 & 6 \\
\hline Wheat offal & 17.5 & 17.5 & 17.5 & 17.5 & 17.0 & 17.0 & 17.0 & 17.0 \\
\hline Palm kernel cake & 7.5 & 7.5 & 7.5 & 7.5 & 7.5 & 7.5 & 7.5 & 7.5 \\
\hline Blood meal & 3.5 & 3.5 & 3.5 & 3.5 & 2 & 2 & 2 & 2 \\
\hline Bone meal & 2 & 2 & 2 & 2 & 2 & 2 & 2 & 2 \\
\hline Palm oil & 1 & 1 & 1 & 1 & 1 & 1 & 1 & 1 \\
\hline Oyster shell & 1 & 1 & 1 & 1 & 1 & 1 & 1 & 1 \\
\hline Vitamin-mineral premix* & 0.25 & 0.25 & 0.25 & 0.25 & 0.25 & 0.25 & 0.25 & 0.25 \\
\hline Salt & 0.25 & 0.25 & 0.25 & 0.25 & 0.25 & 0.25 & 0.25 & 0.25 \\
\hline \multicolumn{9}{|l|}{$\begin{array}{l}\text { Chemical composition } \\
\text { Calculated values (\%) }\end{array}$} \\
\hline $\mathrm{ME}(\mathrm{kcal} / \mathrm{kg})$ & 2817 & 2752 & 2688 & 2623 & 2820 & 2755 & 2691 & 2626 \\
\hline Crude protein & 19.61 & 19.42 & 19.22 & 19.03 & 19.01 & 18.82 & 18.63 & 18.43 \\
\hline Crude fibre & 4.361 & 4.703 & 5.044 & 5.386 & 4.528 & 4.869 & 5.211 & 5.552 \\
\hline Arginine & 1.247 & 1.288 & 1.329 & 1.370 & 1.501 & 1.542 & 1.583 & 1.624 \\
\hline Histidine & 0.542 & 0.532 & 0.522 & 0.512 & 0.444 & 0.434 & 0.424 & 0.413 \\
\hline Isoleucine & 0.732 & 0.716 & 0.700 & 0.684 & 0.649 & 0.633 & 0.617 & 0.601 \\
\hline Leucine & 1.780 & 1.727 & 1.674 & 1.621 & 1.556 & 1.503 & 1.450 & 1.397 \\
\hline Lysine & 1.075 & 1.076 & 1.077 & 1.078 & 0.845 & 0.846 & 0.847 & 0.848 \\
\hline Methionine & 0.323 & 0.321 & 0.319 & 0.317 & 0.292 & 0.290 & 0.288 & 0.286 \\
\hline Phenylalanine & 0.981 & 0.960 & 0.938 & 0.917 & 0.898 & 0.877 & 0.855 & 0.834 \\
\hline Threonine & 0.749 & 0.733 & 0.717 & 0.701 & 0.616 & 0.600 & 0.584 & 0.568 \\
\hline Tryptophan & 0.224 & 0.225 & 0.226 & 0.227 & 0.190 & 0.191 & 0.192 & 0.193 \\
\hline Valine & 1.077 & 1.056 & 1.034 & 1.013 & 0.932 & 0.910 & 0.889 & 0.867 \\
\hline \multicolumn{9}{|l|}{ Determined values (\%) } \\
\hline Dry matter & 89.4 & 90.1 & 89.9 & 89.5 & 89.6 & 90.1 & 89.9 & 90.0 \\
\hline Crude protein & 19.58 & 19.91 & 18.52 & 19.87 & 18.01 & 17.93 & 17.17 & 18.72 \\
\hline Crude fibre & 4.41 & 4.80 & 5.17 & 5.52 & 4.35 & 4.71 & 5.09 & 5.49 \\
\hline Ether extract & 6.71 & 5.41 & 5.84 & 6.71 & 6.27 & 6.31 & 6.74 & 6.75 \\
\hline Ash & 7.15 & 6.53 & 5.84 & 8.95 & 6.50 & 7.21 & 6.52 & 9.27 \\
\hline
\end{tabular}

*Supplied per kg diet: Vit. A, 10000 i.u; Vit. D3, 2000 i.u; Vit. E, 2.5 i.u; Vit. K, 2.0 mg; Riboflavin, 4.2 mg; Pantothenic acid, $5.0 \mathrm{mg}$; nicotinic acid, $20.0 \mathrm{mg}$; choline chloride, $300.0 \mathrm{mg}$; folic acid, $0.5 \mathrm{mg}$; $\mathrm{Mn}, 56.0$ mg; I, 1.0 mg; Fe, 20.0 mg; Cu, 10.0 mg; Zn, 50.0 mg; Co, 1.25 mg.

were recorded weekly. At the end of the $10^{\text {th }}$ week all birds were weighed, slaughtered, eviscerated, dressed and again weighed. The feeding trial lasted for 42 days. The liver, heart and gizzard were cleaned and weighed. At slaughter, blood samples were collected into two test tubes per bird, one with EDTA as anticoagulant and the other 
EGBUNIKE, AGIANG, OWOSIBO AND FATUFE

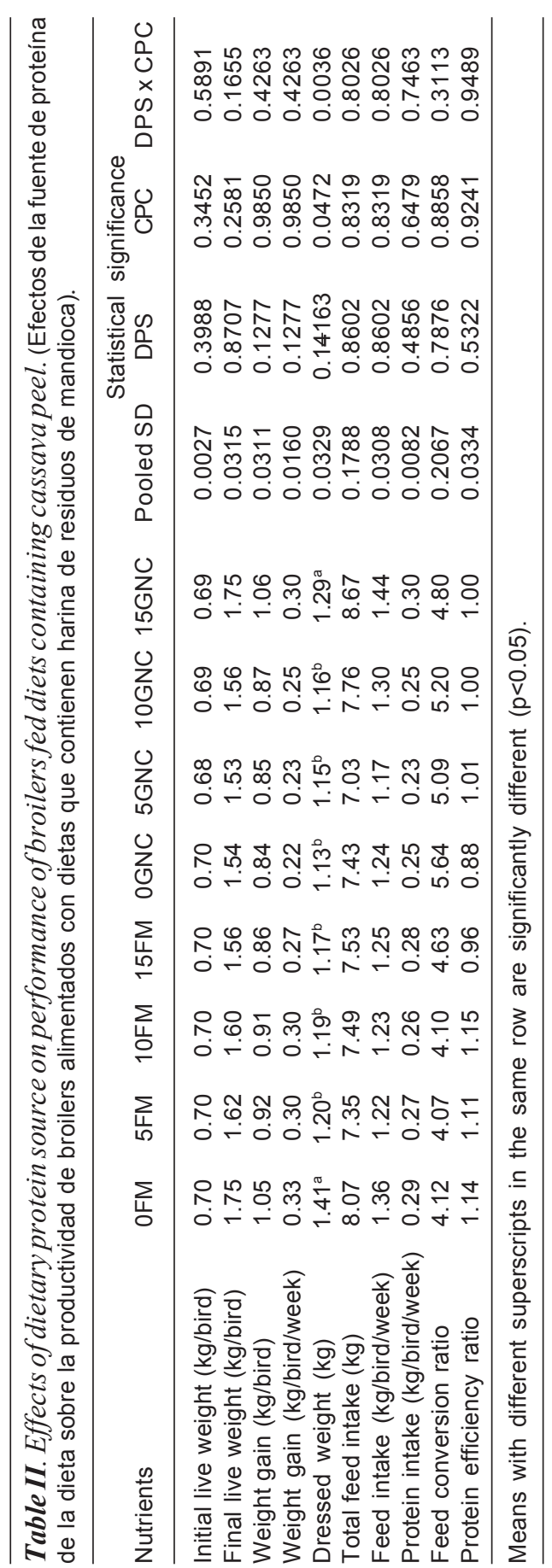

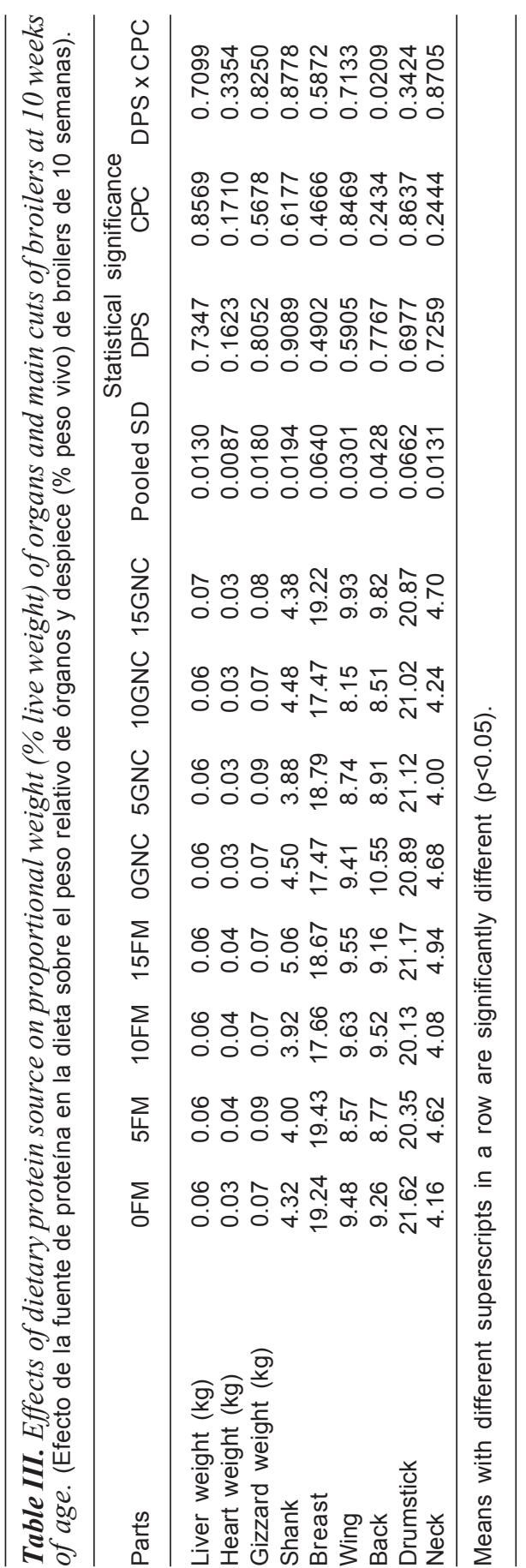

Archivos de zootecnia vol. 58, núm. 224, p. 658. 
without EDTA. The first sample was used for haematological analyses while the second was centrifuged at $4,000 \mathrm{~g}$ for 10 minutes for serum separation. Five dressed birds having a representative weight of the group were randomly picked from each treatment and cut into standard parts namely shank, breast, wings, back, drumstick and neck and weighed separately.

All the diets were chemically analysed according to the standard of AOAC (1990) methods for their proximate composition. Packed cell volume (PCV) was determined by the method of Wintrobe (1933), the red blood cell (RBC), white blood cell (WBC), mean cell volume (MCV), mean cell haemoglobin $(\mathrm{MCH})$ and mean cell heamoglobin concentration (MCHC) were determined as reported by Jain (1986) while haemoglobin (Hb) was estimated as reported by Swensen (1951) and Coles (1986).

Total serum protein was estimated by the biuret method of Reinhold (1953), serum albumin according to Doumas and Briggs (1972) and Peters et al. (1982) and serum globulin was by the method of Rodkey (1965) and Coles (1986). Serum cholesterol was determined according to the methods of Roschlan et al. (1974).

Data were subjected to routine ANOVA from General Linear Model procedures using the software package SPSS 13.0 for windows. Means were separated using Duncan's Multiple Range Test from the same software.

\section{RESULTS}

The composition of the experimental diets is shown in table $\mathbf{I}$. The crude protein content (on dry matter basis) of the diets ranged from $19.3 \%$ in $10 \mathrm{GNC}$ to $22.2 \%$ in $15 \mathrm{FM}$ while the metabolizable energy ranged from 2626 to $2820 \mathrm{Kcal} / \mathrm{kg}$ (on as fed basis).

Final liveweight, weekly weight gain, feed and protein intake as well as feed conversion and protein efficiency ratios did not vary significantly with treatment (table II). Thus while weekly feed intake varied insignificantly from $1.17 \mathrm{~kg}$ in $5 \mathrm{GNC}$ to 1.44 $\mathrm{kg}$ in $15 \mathrm{GNC}$, weight gain varied from $0.22 \mathrm{~kg}$ in $0 \mathrm{GNC}$ to $0.33 \mathrm{~kg}$ in $0 \mathrm{FM}$. Feed conversion ratio and protein efficiency ratio were in the range of 4.07-5.64 and 0.88-1.15, respectively. However, the dressed weights of the birds were significantly $(\mathrm{p}<0.05)$ influenced by the dietary treatments with $0 F M$ and $15 \mathrm{GNC}$ birds being heavier than all the others. On the contrary, the weights of the liver, heart and gizzard as well as the chicken cuts, all of them expressed as percent of final liveweights (table III) were stable with the dietary treatments.

The source of dietary protein did not affect the haematology of the birds but with the increase of cassava in the diets $\mathrm{Hb}, \mathrm{RBC}$, WBC and PCV increased significantly $(p<0.05)$. As regards the corpuscular values (MCV, MCH and $\mathrm{MCHC}$ ), all values obtained remained stable irrespective of dietary treatment (table IV). Total serum protein, globulin and albumin/globulin remained stable with the cassava peel-based diets regardless of the source of dietary protein. However, fishmeal inclusion in the diet resulted in a higher $(\mathrm{p}<0.05)$ serum albumin but lower serum cholesterol $(\mathrm{p}<0.05)$ than groundnut cake. These two indices were elevated $(\mathrm{p}<0.05)$ with dietary inclusion of cassava peel at $5 \%$ after which there was a significant $(\mathrm{p}<0.05)$ depression.

\section{DISCUSSION}

The nutrient composition of the experimental diets shown in table $\mathbf{I}$ is in agreement with the recommendations of Oluyemi and Roberts (1980) for broiler finishers. They were also similar to the diets formulated by Esonu and Bamgbose (2000) and so can be considered adequate for broiler finishers.

That final liveweight, weight gain, feed intake, protein intake, feed conversion ratio and protein efficiency ratio were not influenced by the cassava peel-based diets whether with fish meal or groundnut cake as protein source is in agreement with the 


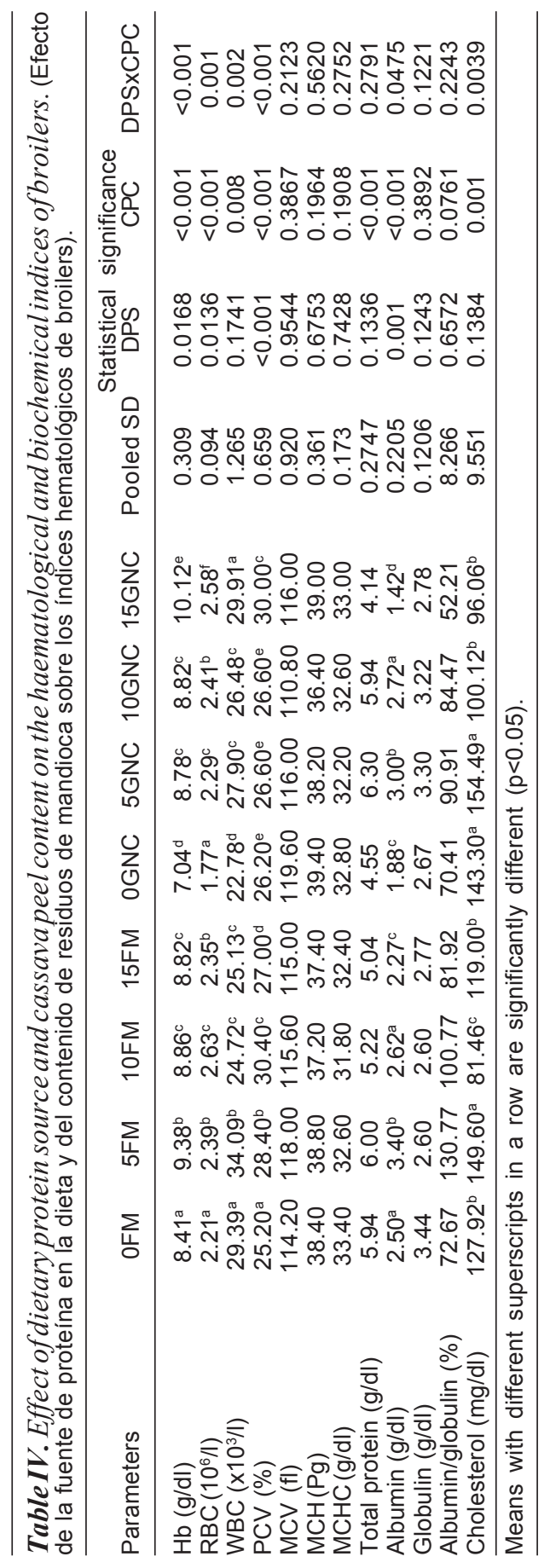

reports on the use of cassava peel up to $15 \%$ in broiler diets by Osei and Duodu (1988); Agunbiade et al. (2002) and Salami et al. (2003). Although final liveweight was not affected by the dietary treatment, dressing weight was best for 0FM and 15 GNC. Result is in agreement with the findings of Willis et al. (1997), Nworgu and Egbunike (1999) and Odunsi et al. (1999). This effect on dressing weight may imply changes in gut transit time of the diets and feed efficiency as shown by Ravindran (1995) and Agwunobi (1999) that could result in changes in the weight of the gastrointestinal tract as a function of dietary treatments. However, that the weights of heart, liver, gizzard and the chicken cuts were not influenced by the treatment conforms with the results of Berri (2000), Nworgu et al. (2001) and Egbunike and Williams (2005) but not with those of Pollock (1997). Body weight gains and feed conversions from the present study are also in good agreement with those in which conventional feed ingredients where fed to Anak strain of broiler of a similar weight range (Oruseibo and Alu, 2006; Oyedeji et al., 2003; Idowu et al., 2003).

The protein source did not have any influence on the haematological indices and corpuscular indices indicating that the diets were ideal or adequate for broiler finishers. However, these values were significantly elevated $(p<0.05)$ as the cassava peel level increased regardless of the protein source, but are within the normal range reported in literature (Jain, 1986). This suggests that the diets with cassava peels promoted a better haematological milieu as observed in rats by Adejumo (2004).

The adequacy of the diets is also shown by the stability of the serum protein, globulin and albumin/globulin ratio values of the birds on the different diets regardless of protein source and cassava peel levels. The protein source however significantly influenced the serum albumin and cholesterol levels with these increasing and 


\section{DIETARY PROTEIN ON PERFORMANCE AND HAEMATOLOGY OF BROILER CHICKENS}

decreasing, respectively, with fishmeal. The values in these parameters of this study are at variance with those of Nworgu (2004) with albumin being lower and albumin/ globulin ratio and cholesterol being higher. The cholesterol values are however generally within the normal range according to Sturkie et al. (2000). The increase in the albumin level at $5 \%$ cassava peel levels regardless of protein source may be construed as implying that the improvement

\section{REFERENCES}

Adejumo, D.O. 2004. Performance, organ development and haematology of rats fed sole diets of graded levels of cassava flour and soybean (Soygari) as substitutes for energy and protein concentrates. Trop. J. Anim. Sci., 7: 57-63.

Agunbiade, J.A., O.A. Adeyemi, O.A. Adepoju and O.A. Lawal. 2002. The use of whole cassava meal and leaf meal in broiler diets. Trop. J. Anim. Sci., 5: 161-173.

Agwunobi, L.N. 1999. Performance of broiler chicks fed sweet potato meal (Ipomea batatas L) diet. Trop. Anim. Hith. Prod., 31: 383-389.

Antunes, P.L. and P. Sgarbieri. 1980. Effect of heat treatment on the toxicity and nutritive value of dry bean ( $P$. vulgaris) protein. J. Agric. Food Chem., 28: 935-938.

A.O.A.C. 1990. Association of Official Analytical Chemists. Official Methods of Analysis, $15^{\text {th }} \mathrm{Ed}$. Washington, D.C.

Barbour, G., J.D. Latshaw and B. Bishop. 1993. Lysine requirement of broiler chicks as affected by protein sources and method of statistical evaluation. Brit. Poult. Sci., 34: 747-756.

Bello, O.A. 1984. The use of agro-industrial byeproduct in livestock feeding. Nig. J. Anim. Prod., 11: 22.

Berri, C. 2000. Variability of sensory and processing qualities of poultry meat. World Poultry Sci. J., 56: 209-224.

Coles, H. 1986. Veterinary Clinic Pathology, $4^{\text {th }}$ ed. W.B. Saunder Co. Philadelphia.

Dipeolu, M.A., D. Eruvbetine and T.J. Williams. 1996). Indigenous chicken rearing under village conditions. Int. J. Anim. Sci., 11: 63-67.

Doumas, B.T. and H.G. Briggs. 1972. Serum albumin of the haematology referred to earlier was best at this level.

\section{CONCLUSION}

The results on final liveweight, weight gain, feed conversion ratio and protein efficiency ratio obtained in this study indicate that broilers could be raised on cassava peel-based diets using groundnut cake as the protein source.

by bromocresol green binding. Standard Methods Clinical Chemistry, 7: 171-179.

Egbunike, G.N. and J.T. Williams. 2005. Utilization of crude testis extracts to enhance broiler production in the humid tropics. ASSET (In press).

Esonu, B.O. and A.M. Bamgbose. 2000. Evaluation of the nutritive value of raw variegated cocoyam corn meal (Caladium hortulanum) for broiler chickens. Nig. Poult. Sci. J., 1: 42-51.

F.A.O. 1986. African Agriculture, the Next 75 years. Rome. Italy.

Idowu, O.M.O., D. Eruvbetine, O.O. Oduguwa, A.M. Bamgbose and S.S. Abiola. 2003. Response of finishing broiler chickens fed three energy/ protein combinations at fixed E:P ratio. Nig. J. Anim. Prod., 30: 185-191.

ILCA. 1980. International Livestock Centre for Africa. Livestock Production in Africa. In ILCA: The First Year. Addis Ababa. Ethiopia.

Jain, N.C. 1986. Schalm's Veterinary Haematology. $4^{\text {th }}$ ed. Lea and Febiger. Philadelphia. USA.

Larry, E.N. 1993. Broiler Feeding and Management. Poultry Int., 32: 70-72.

NRC. 1994. Nutrient Requirements of Poultry. National Academy Press. Washington, DC.

Nworgu, F.C. 2004. Utilization of Forage Meal Supplements in Broiler Production. Ph.D Thesis, University of Ibadan. Ibadan.

Nworgu, F.C. and G.N. Egbunike. 1999. Performance characteristics of broilers fed diets with soybean and groundnut cake as protein sources. Trop Anim. Prod Invest., 2: 51-59.

Nworgu, F.C., G.N. Egbunike and F.I. Ogundola. 2000. Performance and nitrogen utilization of broiler chicks fed full fat extruded soybean meal 


\section{EGBUNIKE, AGIANG, OWOSIBO AND FATUFE}

and full fat soybean. Trop. Anim. Prod. Invest., 3: $47-54$.

Nworgu, F.C., G.N. Egbunike, F.I. Ogundola, R.A Salako and O.E. Fakeye. 2001. Effects of different protein levels on the performance and carcass characteristics of broilers. ASSET series $A, 1(2)$ : 75-87.

Odunsi, A.A., G.O. Farinu, J.O. Akinola and V.A. Togun. 1999. Growth, carcass characteristics and body composition of broiler chickens fed wild sunflower (Tithonia diversifolia) forage meal. Trop. Anim. Prod. Invest., 2: 205-211.

Olorede, B.R., Y. Saidu, I.M. Abdu and O.A. Akinloye. 2002. Growth performance and economics of cockerels fed cassava flour based diets. Proc. $7^{\text {th }}$ Ann. Conf. Anim. Sci. Assoc., Sept. 16-19. Abeokuta. p. 247-248.

Oluyemi, J.A. and F.A. Roberts. 1980. Poultry Production in Warm Wet Climates. Spectrum Books Ltd.. Ibadan. Nigeria.

Oruseibo, S.M. and E.U. Alu. 2006. Response of broiler birds to supplementation of ascorbic acid-vitamin C. Nig. Poultry Sci. J., 4: 12-15.

Oruwari, B.M., B.T. Sese and O.O. Mgbere. 1995. The effect of whole palm kernel on broiler performance and production cost: energy protein ratio. Int. J. Anim. Sci., 10: 115-120.

Osei, S.A. and S. Duodu. 1988. Effects of fermented cassava peel meal on the performance of broilers. Brit. Poult. Sci., 29: 671-675.

Oyedeji, J.O., J.O. Atteh and O.O. Ogbonini. 2003. Effects of dietary ammonium sulphate (AS) on the performance and abdominal fat of broilers. Nig. J. Anim. Prod., 30: 9-14.

Peters, T., G.T. Biamonte and B.T. Doumas. 1982. Protein (total protein) in serum, urine and cerebrospinal fluid: albumin in serum. In: Selected methods of clinical chemistry. Vol. 9 (W.R. Paulkner and S. Meites, Eds.). American Association for Clinical Chemistry, Washington, D.C.

Pollock, D.L. 1997. Maximizing yield. Poul. Sci., 76: 1131-1133.

Ravindran, V. 1995. Performance of broiler chicks fed sweet potato meal (Ipomea batatas) diet. Trop. Anim. HIth. Prod., 31: 383-389.

Reinhold, J.G. 1953. Standard methods of clinical chemistry. M. Reiner, ed. Vol. 188. Academic Press. New York.

Rodkey, F.L.O. 1965. Globulin direct determination. Clin. Chem., 11: 486.

Roschlan, P., E. Bernet and W. Gruber. 1974. Enzymatische bestimmung des gesamt cholesterium in serum. J. Clin. Biochem., 12: 403-407.

Salami, R.I., A.L. Ogunmola and O. Akindoye. 2003. Cassava peel processed by different methods as substitute for maize in cockerel starter diets. Proc. $28^{\text {th }}$ Ann. Confr. Nig. Soc. Anim. Prod., 1620 March. Ibadan. p. 177-179.

Sibbald, I.R. 1982. Measurement of bioavailable energy in poultry feed stuffs. A review. Can. J. Anim. Sci., 4: 938-1048.

Sturkie, P.O., W. Hazel and R. Wood. 2000. Animal Physiology, $3^{\text {rd }}$ ed. Springer-Vallock. New York.

Swensen, M.T. 1951. Effects of vitamin $B_{12}$ and liver meal on the haematology of chicks fed on all protein ration. Anim. J. Vet. Res., 12: 147- 151.

Tewe, O.O. 1983. Thyroid cassava toxicity in animals. In: Cassava toxicity and thyroid: research and public health issues. Proc. Int. Workshop on Cassava Toxicity (F. Delange and R. Alwuwalia, eds.). Ottawa. Canada. p. 114118.

Tewe, O.O. 1992. Detoxification of cassava products and effects of residual toxins on consuming animals. In: Roots, tubers, plantains and bananas in animal feeding. Proc. FAO expert consultation, CIAT, Cali, Columbia, 21-25 January. 1991. p. 81-89.

Tewe, O.O. and G.N. Egbunike. 1992. Utilization of cassava in non-ruminant feeding. In: Cassava as Livestock Feed in Africa (S.K. Hahn, L. Reynoids and G.N. Egbunike, eds.). IITA, Ibadan and ILCA. Addis Ababa. p. 28-38.

Thackie, A.M. and J.E. Flenscher. 1995. Nutritive value of wild sorghum fortified with leucaena (Leucaena leucocephala Wh. Lam). Bull. Anim. HIth. Afr., 43: 223-275.

Willis, W.L., C. Murray and C. Talbott. 1997. Evaluation of leaves as a litter material. Poultry Sci., 76: 1138-1140.

Wintrobe, M.M. 1933. Microscopic examination of blood. Am. J. Med. Sci., 185: 58-59.

Archivos de zootecnia vol. 58, núm. 224, p. 662. 